\title{
Norway's strategy to cope with Corona pandemics
}

\author{
Danuta A. Tomczak
}

Østfold University College, associate professor dr, Halden, Norway

Address for correspondence: danuta.a.tomczak@hiof.no

\section{Abstract}

Pandemics sudden influx claimed reaction from national authorities to protect their societies and ensure an operative functioning of the public health care. This article explains how the Norwegian government reacted in this unpredictable situation, which lockdown option was chosen and what economic consequences the applied measures might bring. How to weight public health against economic offers and future downturn? Trade-offs are compound and it is too early to conclude which country has made the best choice.

Key words: health care, pandemic, state policies, globalisation failures

Stowa kluczowe: ochrona zurowia, epidemia, polityka rządu, błęldy globalizacij

\section{Introduction}

Norway - as many other countries, chosen to lockdown the country from 12th of March to prevent spread of infection by COVID-19 virus, but comparing with other Nordic neighbours the regulations framework was 'in between ' - less restrictive than in Denmark and Finland, but more restrictive than in Sweden and Iceland. Since the 11th of April and so beginning of May several restrictions have been removed or eased, to attempt return to "normal life". Here the introduced regulations, economic support, and their impact so far, are presented. The large number of hasty decisions and actions raised up the debates on outcomes of the above for public health and the society.

\section{The pandemics regulations and decision-making authorities}

The decisions on strategy towards public health protection, rules for regulations and economic support, due to pandemics, have been made by the government, represented by prime minister and relevant ministers (of health \&social care, justice, education, finance).

Actions and decisions are prepared and discussed in the RCU - The Government Corona Board, where participated Health institutions give their professional recommendations, but government decides. The government is not obliged to follow the given recommendations, and makes decisions out of its own assessment of the required security. The RCU members are: The Norwegian Institute of Public Health and The Norwegian Health Directorate, represented by the Director-General of each, and the government members - the respective ministers and the prime-minister. Institute of Public Health (www.fhi.no) and Health Directorate (www.helsedirektorate.no) work out professional analyses and conducts research, submitting their expert opinions to the Ministry of Health and Social Care. The current information on number of tests, infected persons, hospitalized patients, patients under intensive treatment and number of deaths are reported by local authorities - the municipal physician - to the Institute of Public Health. Institute is under Ministry of Health and Social Care.

The decisions made 12th of March to cope with pandemics were following:

- Closing kindergartens, schools and other educational institutions; distance learning

- Home-based office for personnel of most institutions

- Closing training centres, hairdressers, theatres etc

- No sport- and cultural arrangements

- No visits in older people homes \& nursing institutions

- No more than 5 persons together, keeping $2 \mathrm{~m}$ distance

- No flights abroad and limited capacity of local flights

- No travel to leisure houses outside own municipality and closing of skiing centres 
- Border controls, no access for persons not living or working in Norway

- Home quarantine to weeks after arriving from abroad or being in contact with a virus-infected person

- Staying at home, not travelling, limited using of public transport was recommended

Shops, coffees, restaurants could decide self to keep open or close, but have to introduce new routines for cleaning, disinfection and control of distance between customers/limiting number of available tables/sitting places. It was and still is obligatory to wash hands before entering a shop, pharmacy, coffee bar.

It was allowed to go out, walk outside without time limit, go shopping, going to restaurant if rules for keeping distance and number of people together were hold.

Citizens are currently informed on pandemic spread in their home location. Local municipality authorities and the municipal physician send link to phones of the inhabitants where they find updated information on municipality`s virus spread, current rules to follow, numbers of tested persons, numbers of infected, hospitalized and dead of virus. There is also information on how to contact health centre in case of suspected infection and testing options, and where to call with questions. For persons with no symptoms, family doctors are available for consultations as before, just following the new mandatory safety procedures.

The applied lockdown strategy, in a lighter version than the Spanish or Italian ones, has been accepted and respected by majority of citizens $-90 \%$ of public opinion respondents agreed with that the government approach was correct. Anyway, it raised debates in both directions - for more restrictive and much less restrictive tactic should have been applied.

Easing of restrictions 7th of April and 7th of May:

- Pandemics regarded under control 7.04. - kindergarten opened from 20.04. and schools 1-4 class from 27.04., all primary schools from 11.05 .

- Hairdressers, physiotherapist, dentists a.o. can open from 27.04 .

- Travel to leisure places allowed from 20th of April

- Cinema, theatres, concerts can be hold from May 15th for max 50 people

- From June number of participants of organized arrangements can increases to 200

- Sports training is allowed under safety regulations, and football games without public from June 15th

- From 15th of May private meetings at home can gather up to 20 people, keeping $1 \mathrm{~m}$ distance

For all the above apply rules on hand hygiene, distance of $1 \mathrm{~m}$ between persons who are not living in the same household, and washing and disinfection of common areas. Groups of children in kindergartens should not be bigger than 6 pr assistant, at school 15 (classes 1-4) and 20 (classes 5-7) pr. teacher, banks placed $1 \mathrm{~m}$ in between. That means new organization of teaching at schools, new classrooms and more teachers/cleaning personnel to be employed.

\section{The pandemic expansion}

There is no clear picture neither in Norway nor in any country of virus dissemination, because number of done tests is not sufficiently high. Only people with clear Corona-symptoms, hospital personnel, military, have been tested. There is also proved that some infected persons do not have symptoms and do not get sick. Virus has been transferred to Norway from crowded bars in Ischgl, Tirol, Austrian Alps by skiers, most of them from Oslo region, in February. Hospitals were ordered to prepare special subdivisions for COVID-19 infected, and increase capacity by postponing scheduled ordinary patients' treatment. As the storage of protection outfits and equipment, mostly imported, has been quickly drained, so local companies shifted to production of protection dresses, face masks, shields. Neither in Norway nor in Sweden face masks have been imposed to be applied in public places. In the health authority's opinion face masks do not help against spreading of virus, and may have the opposite effect, because people wearing mask touch face with hands much more often than otherwise, and can transmit virus from hands to mouths, eyes and body.

Communication of facts, due to media diversity, is not a simple task, a lot of false or unofficial info circulates in social media. Even if officially presented numbers are correct, so the context and relative values are missing, as what models have been applied in calculations or how predictions have been made. Announcing the number of sick/ dead people does not say much when the listener is not informed how many inhabitants a country or a city has.

First- number of tested persons helps to judge how good proved the number of infected persons might be.

It is tempting to conclude that the lockdown strategies were more effective than the "Swedish model" - prevent, not lock, to breed the flock immunity - but, in my opinion, it is too early to evaluate the reasons for differences and results for each listed society. We need additional factors to analyse and longer observation period to get the credible explanation. Age-structure of population might be one of these factors, urbanization and composition of population another ones. Hans Bergstrom points out (Bergstrom 2020) that $25 \%$ of Swedish population is of non-Swedish descent, and immigrants are highly overrepresented among COVID-19 death. It is just an example, which may contribute to explain higher death frequency in Sweden.

Concerning Norwegian lockdown strategy, it was recently debated and questioned why the government decided to force much stronger restrictions than recommended by the health authorities. They did not recommend closing of schools and kindergartens, and after closing recommended to re-open 23rd of March. The Prime Minister answer was that the government must consider not only health, but also other factors to guarantee security. Another not followed recommendation has been the quarantine period - 14 days rule, while 10 days recommended by Public Health Institute.

In general, there is high level of trust to government and public institutions, so the society followed the stringent rules, believing that authorities do the best. 


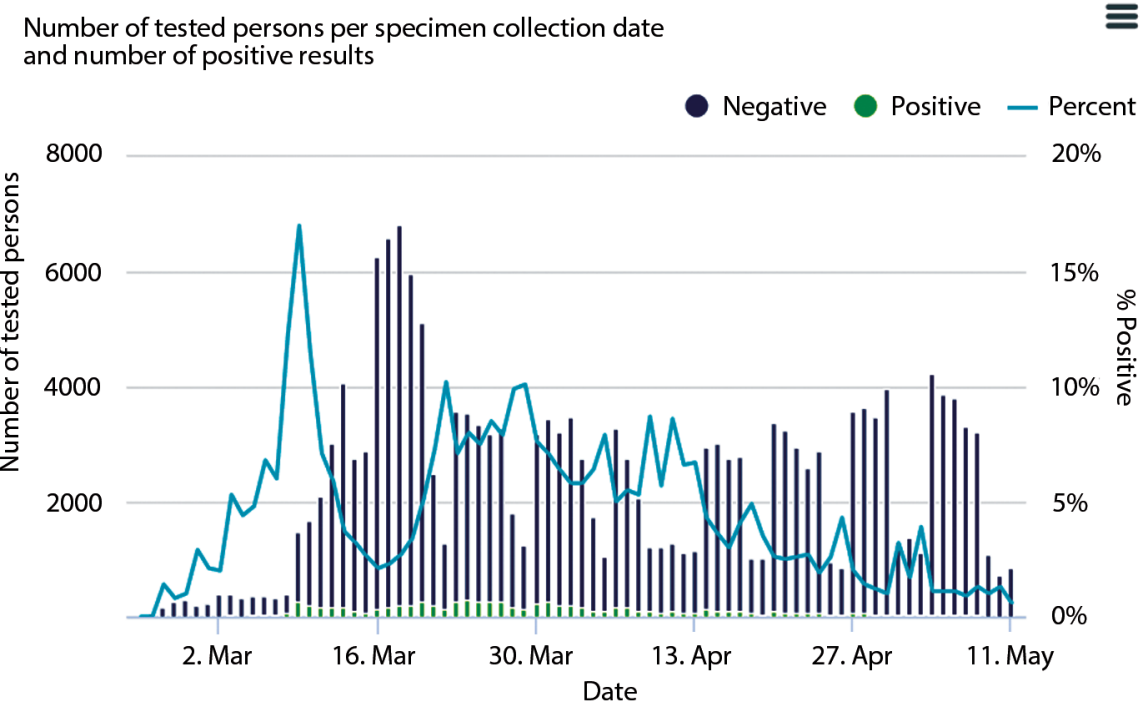

Norway`s Health and Social Cares minister Bent Hoeye declared that epidemic was under control 7th of April, and the government decided to open-up gradually.

Next - what numbers are relevant for evaluating of pandemics strategies. Let us look to Nordic countries statistics.

Figure 1. Tested persons in Norway

Table I. COVID-19 overview for Nordic countries (until the 19th of May 2020)

\begin{tabular}{|l|c|c|c|c|c|}
\hline Country & Population in million & Number infected & Infected per 100 000 & Number of Death & Death per million \\
\hline Sweden & 10,3 & 30377 & 234 & 3698 & 363 \\
\hline Norway & 5,4 & 8249 & 155 & 233 & 43 \\
\hline Denmark & 5,8 & 10968 & 189 & 548 & 95 \\
\hline Finland & 5,5 & 6380 & 116 & 300 & 54 \\
\hline Iceland & 0,364 & 1802 & 510 & 10 & 28 \\
\hline
\end{tabular}

Source: Norwegian Institute of public Health; https://www.fhi.no/en/id/infectious-diseases/coronavirus/ downloaded 19.05.2020. and SSB, own selection of data.

\section{Economic consenuences of pandemics actions}

It is obvious, that sudden lockdown decisions had to be followed with compensation for activity stop, and government was quick and generous. To get the right picture of state support, a quick notice about the Norwegian welfare state system: all people living in Norway are members of public health insurance system and get free access to all medical treatment. Public schools, including tertial education, are free of charge, students get low-interest loan and scholarship, kindergartens are free of charge for low-income families; $90 \%$ of children 1-6 are in kindergartens. Employees have right to compensation of $62,5 \%$ of wage/salary if personnel are directed on leave or terminated (unemployment benefit 2 years). Job seekers can also get state support up to three years to enhance qualifications for new job.

The government settled hasty support packages to almost all suffering from lockdown units, billions of crowns run out daily, not always best targeted.
Economists were concerned for costs of the lockdown strategy. Already 7th of April the expert group, appointed by the Directorate of Health, and led by prof. Steinar Holden from University of Oslo, presented the report "Socio-economic evaluation of infection control measures - covid-19". The group analysed results for three strategies of infection control: 1. turn down, 2. turn down and hold, 3. slow down. The calculated costs are high, stretching over decennium, highest for strategy 2.

The Ministry of Finance presented Revised National Budget for 2020 on 12th of May, with essential changes. Deficit increases from 227,6 bill NOK to 479,6 bill NOK, unemployment rate goes up from predicted $2,2 \%$ to $5,9 \%$, GNP fall is expected to be $-4 \%$. This means that Corona-related expenses, as support to business, culture, sport, tourism, municipalities a.m., are predicted to be 252 billion NOK in 2020, (105 billion PZN or 24 billon US dollars). https://www.regjeringen.no/en/ aktuelt/a-budget-to-help-us-safely-reclaim-ordinary-life/ id2701787/ (downloaded 13.05.2020). 


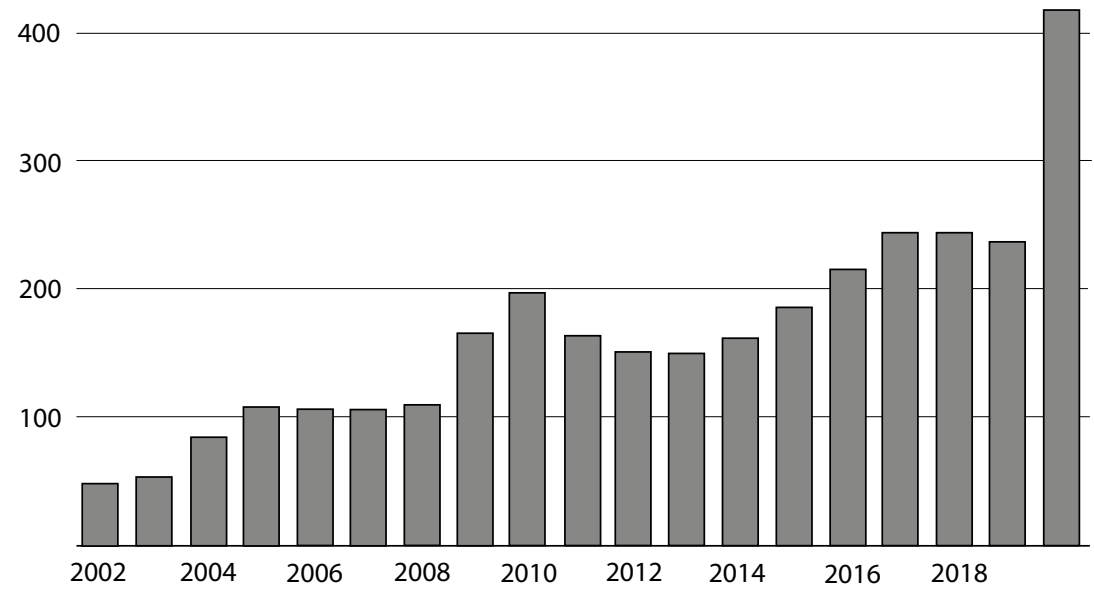

Figure 2. Norway's money transfers from petroleum fund to the state budget (Billion NOK, current prices) Source: Grafikk: Petter Winther/DN • Kilde Revidert statsbudsjett 12.05.2020.

Fortunately, Norway owns a big oil fund (Government Pension Fund Global), where incomes from petroleum sector have been located since 1970s, so government has reserves to cover the worsen state budget deficit (https://www.nbim.no/en/).

The current debates on government strategies for control over pandemics, distribution of financial backing up, plans to return to "normal life" are split over diverse issues, so here those of common attention will be shortly stated.

\section{Were government's decisions and measures against pandemics adequate?}

The Government has got special rights for imposing hasty Corona-decisions - the authority to add to or depart from certain legislation as far as is necessary to safeguard the intention of the law. It was passed unanimously in the Norwegian parliament - Storting - on Saturday 21st March, first valid for 4 weeks, later prolonged to 27th of May. (https://stortinget.no/en/In-English/Aboutthe-Storting/News-archive/Front-page-news/2019-2020/ corona-act-extended-until-late-may). Parliament has also made several budgetary decisions on support of health sector and economy, due to problems related to pandemics. (https://stortinget.no/en/In-English/Aboutthe-Storting/News-archive/Front-page-news/2019-2020/ the-stortings-decisions-relating-to-the-coronavirus-andthe-economy/).

The closing of schools and kindergarten has been controversial, as the health authorities did not recommend it, so it was the solely government's decision. Ministry of Children \& Families got the report from Directorate for Children, Families and Youth on 20th of April, pointing out challenging condition for vulnerable children, as not all parents can assist their children in home learning, and, in addition, children can be exposed for outrage. Researchers are concerned with long-term effects of schools- and kindergartens closing for future labour market. In newly published article Løken and Salvanes estimate the total cost of closed schools in 20 days for 11 billion NOK ([9]: 19), due to lost learning. They assume that the weakest groups in the society will carry most of these costs.

Compensation to business has also been criticised as not properly targeted, especially state's taking over labour costs of employees on leave (state pays $80 \%$ of wage from day 3 ) and $80 \%$ of fix costs when firms keep closed. Many economists warn that this generous support encourages to close or reduce activity instead of making effort to keep it running. They propose to give compensation to salary budget instead of, because the lower costs of labour for the company will stimulate to activity and contribute to economic growth (Henriksen, [5]: 9).

The government's answers emphasise that lockdown prevented spread of infection. Up to 18th of May 198.362 people were tested, 8.249 reported infected, 233 died (152 in age over 80 ). The R-number, which shows how many people one infected infects, fell to 0,61 (for 20.04. - 18.05.).

A new tool for preventing infection spreading has been applied, a contact-tracing mobile app "Infection Stop", developed by state company Simula Research Laboratory, available for downloading 17th of April from Apple App Store og Google Play Store. Downloading of the app is voluntary. The app should give the user information if he/she was in contact with Corona-infected person and also give the Health authorities data on users' movements and data on infected persons in different regions via GPS and Bluetooth, for better geographically targeted measures of prevention and for further research. Central server holds collected data. In the first days around 1,6 mill users downloaded application, later the number has gone down to 0,69 mill (8th of May) by unlike reasons fell to 0,61 (https://www.fhi.no/en/id/infectious-diseases/coronavirus/daily-reports/daily-reports- 


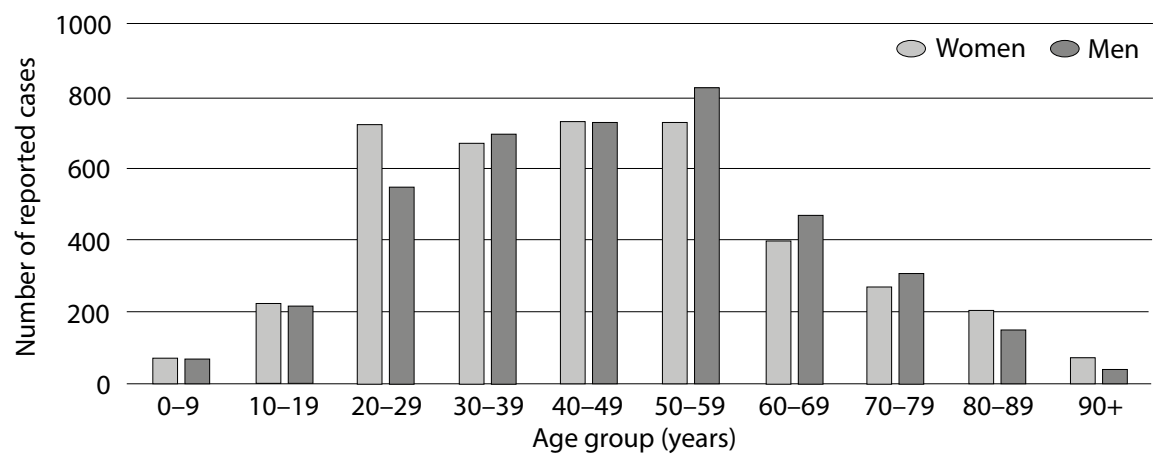

Figure 3. Number of conrmed COVID-19 cases by age and sex in Norway

Source: https://www.fhi.no/en/id/infectious-diseases/coronavirus/daily-reports/daily-reports-COVID19/18.05.

COVID19/ as 18.05.2020). Norwegian Data Protection Authority claimed from Public Health Institute to develop rules of protection, due to not allowed surveillance and registering of users' movements. The app also consumes much battery power, so phones need frequent charging. So, up to now, the app has not been, as expected, an effective measure of advanced virus protection tool.

\section{What the pandemics disclosed}

Each disaster - whether it is a deep crisis or epidemics, should give us valuable experience and new knowledge. It is too early yet for Corona pandemic suppositions, but some statements can be already sat:

- Globalisation, run by multinational companies, has shown its crooked face

- Health sector has been partly managed as business, not only as a social good

- Ecological balance and social fairness have been distorted in run for profit

When hospitals and other health institutions registered insufficient storage of protective kit and equipment or lack of medicines, so leverages were stuck, as most of items in last years have been imported from Asia. Suddenly the problem of local production of essential products, in emergency, came up. In week when the lockdown of the country was announced, 12th of March, Norway has had infection protective equipment for 4-40 weeks: surgical mouth bands and surgical hats for 4 weeks, gloves for 7, dresses for 18 weeks (Stortinget.no, published in Aftenposten 14.05.2020, p. 5). Later prices jumped up, forged products arrived, exposing medical personnel and patients to danger. Local production had to be started. It became obvious, that not only unit costs of production, but also national security, climate protection against transport emissions, and other factors have to be considered for safe location of production. Numberless chains of production of parts for a single product are profitable for owners, mainly multinational companies, but high social costs for citizens, what pandemics has revealed. Most of the countries import their medicines, only 18 are net exporters. However, according to Melchior concentration of production is observed only in selected products, so Covid-19 triggered demand shock, and was not an effect of market supremacy ([10]: 2-4). As the hospitals had to release many beds in emergency for Corona-infected, so 250.000 consultations and operations were postponed, while most of these beds stayed empty. It costs...

Globalisation process, rapidly progressing since 1990s, has also increased financialization of national economies, due to free and massive capital movements, ongoing privatization of state property, public services and trading with data. These changes have also affected the health sector. Economic pressure forced hospitals to reduce number of intensive treatment beds - as for example Italy reduced these from 922 per 100.000 inhabitants in 1980 to 275 in 2020 ([7]: 12). The similar process has been running in Norway - many local hospitals were closed down, limiting proximity of available health services in small places. Outsourcing of services to private actors made a divide between modest and severe sickness treatment institutions, so care dispersal resulted in skewed distribution of resources, in favour of private easy-care and disease tests suppliers. Public hospitals are pressed, use all capacity of available beds for scheduled patients, as they get paid per patient/treatment. Generally, $15-20 \%$ beds should be kept in reserve for emergency purpose, as COVID-19 proved the lack of, but hospitals have no resources to keep empty beds or many expensive respirators in emergency. Since 1980s the number of hospitals in Norway has been reduced by $50 \%$ and the health sector emergency has been mistreated, what several doctors expressed ([6]: 10). Lack of emergency reserves caused the panic in hospitals, pressing lockdown solutions, much costlier than keeping emergency reserves. Professor of epidemiology dr Eivind Lund proposes to open up the society and only protect high risk groups, what in case of Corona are people in nursing homes, where $59 \%$ of Covid-19s death in Norway occurred, giving the death rate there 346/100.000, against 4,3/100.000 for Norway ([8]: 38). Similar proportions of death cases apply also to Sweden. 
Therefore, in my opinion, pandemics should be an incentive to new ideas of health and care services organization and financial system, including public-private service tasks detachment and nursing treatment concepts for elderly generation. Perhaps another form of handling of old people than nursing homes is desirable?

The imposed lockdown measures have been positive for environment, as the travelling and transport got limited, so the use of fuels and emissions. Restrictions and staying at home forced many to reflect over the current life style and its necessary modification, to slow the rolling climate disaster. The plan for future pollution control must be settled and followed up.

Not all information on consequence of virus infection is yet sorted out and analysed, but it is quite clear that pandemics hit hardest the low-income groups of the society. They seldom have jobs which can be done from home-office, live in densely populated city blocks, cannot help children with distant teaching. Several children might be also exposed to violence, either in family or neighbourhood. According to statistics, up to 8th of May, 462.000 people in Norway applied for unemployment benefit, three times as many as in the entire 2019. It takes time to process so many applications, so pay-outs are delayed, again, the exposed families are struck.

\section{Conclusions}

It is extremely difficult to conclude on effects, as the facts are often incomplete or not verified, but some cautious deductions can be made.

1. Norway is a country with high level of trust to governing institutions, so people accepted

and followed restrictions and rules given by government due to pandemics

2. The government's lockdown strategy, with social distancing, but freedom to move outside, has been relieved gradually in April and May
3. Information on 'state of affairs ' was good and available in several languages, both locally, by Municipal Doctor messages, and centrally on Institute of Public Health Institute pages

4. The numbers of infected, sick and dead is low, higher in Oslo, very low in North; the hospitals capacity has been adapted and sufficient for treatment of infected

5. There are controversies around government's strategy of lockdown, since health authorities did not recommend closing of schools and long quarantine

6. The government was generous in support of closed down business and employees who lost jobs, but economists point out that not all initiatives have been properly targeted

7. The costs - now and in coming years - are calculated; this are just projections which have to be revised thereafter, but no doubt, the costs are high

8. International cooperation calls for revised patterns of flows and rules

It is questionable why Corona has got so much attention and set out all other important subjects and problems from media and politics apart. I feel overwhelmed of all details on infections here and there, or number of died of virus, unrelated to population and normal yearly death rates, which show that the relative numbers are still low, even for the most exposed countries. Is this medias overreaction pushed by social media, fake news, massive fear? There is no doubt that Corona virus brings rapid spread of infection, but several doctors explain that high death rate of the sick older patients is caused by bacterial infection afterwards, due to antibiotics resistance, not virus itself. Since in Norway antibiotics use and resistance against is low, much lower than, for example, in Italy, so high number of deaths could be the result of antibiotics resistance, not predominantly COVID-19 virus infection? Experience and further analyses will hopefully give us the answer in near future.

\section{References}

1. Bergstrom H., The Grim Truth About the Swedish Model, Project Syndicate, 24.04.2020.

2. Borio C., Restoy F., Reflections on regulatory responses to Covid-19 pandemic, BIS, FSI Briefs, April 2020; 1.

3. COVID-19, Dagsrapporter, 2020, www.fhi.no

4. Glover A., Heathcote J., Krueger D., Rios-Rull J.V., Health Versus Wealth: On Distributional Effects of Controlling a Pandemics, NBER Working Paper Series, 2020; WP 27046.

5. Moen E., Natvik G.J., En prinsipiell tilncerming til økonomiske tiltakspakker mens vi bekjemper koronaviruset, "Samfunnsøkonomen" 2020; 2: 6-11.

6. Holm T., Hvem skal betale for dårlig beredskap?, "Halden Arbeiderbladet" 30.04.2020: 10.

7. Lambert R., Rimbert P., Til neste gang verden går under, "Le Monde Diplomatique"; April 2020: 12-13.

8. Lund E., Det er på tide å åpne opp og skifte strategi, "Dagens Næringsliv", 20.05.2020; 115: 38-39.

9. Løken V.K., Salvanes K.G., Langsiktige konsekvenser for familier, "Samfunnsøkonomen” 2020; 2: 18-23.

10. Melchior A., Handelen med medicinske varer og COVID-19, "NUPI COVID-19 BRIEF" 2020; 6.

11. Kelly E., Europe eases the COVID-19 lockdown: 'We are very worried about the next phase', 07 May 2020.

12. Rapport fra ekspertgruppe, Samfunnsøkonomisk vurdering av smitteverntiltak - covid-19, 07. April 2020: 1-7.

13. Wagner R.E., How Can Economics Enable Us Better Understand COVID-19?, George Mason University, Dept. of Economics, Working Paper 2020; 20-14: 1-11. 